\title{
Analisa Pengaruh Luas Penampang Penghantar dan Cuaca Terhadap Rugi Daya Akibat Korona Pada SUTET 150 kV (Studi Kasus: Gardu Induk Bangkalan - Gardu Induk Sampang)
}

\author{
Ibnu Hajar'; Tito Dias Fernando² \\ ${ }^{1}$ Departemen Elektro, Sekolah Tinggi Teknik PLN \\ ${ }^{2}$ Alumni Departemen Elektro, Sekolah Tinggi Teknik PLN \\ 1ibnu.hajar@sttpln.ac.id
}

\begin{abstract}
In the transmission of electrical power to consumers will got losses of power. Raising the voltage is an alternative to this problem but it creates new problems because the higher the voltage is increased the corona will occur. The impact of the corona in addition to damaging equipment, noise and disturbing radio waves, the corona also causes power losses that are proportional to the length of the transmission line. This study uses a quantitative method, by calculating the corona power losses by comparing 4 different cross-sectional areas of the conductor and 4 different air temperatures. The results of this study found that the smaller the cross-sectional area of the conductor the power losses due to corona are smaller, conversely the greater the cross-sectional area the greater the power losses. At the smallest cross-sectional area of $282.6 \mathrm{~mm} 2$ the power losses that occurred were $2.013 \%$ and at the largest cross-sectional area of $378.7 \mathrm{~mm} 2$ the power losses were $5.251 \%$. While the influence of air temperature, the lowest corona losses occur at 29 OC which are 1,223,886 kW and the biggest occur at $240 \mathrm{C}$ which are $1,373,419 \mathrm{~kW}$, so the higher the air temperature the smaller the corona losses, conversely the lower the air temperature then the higher the corona losses that occur.
\end{abstract}

Keywords: Quality of electricity transmission, corona, the cross-sectional area of the conductor, the influence of the air temperature

\begin{abstract}
ABSTRAK
Dalam penyaluran daya listrik ke konsumen akan mengalami rugi daya penyaluran. Menaikkan tegangan adalah alternatif dari masalah ini namun menimbulkan permasalahan baru karena semakin tinggi tegangan dinaikan akan menimbulkan peristiwa korona. Dampak dari korona selain merusak peralatan, berisik, dan mengganggu gelombang radio, korona juga menimbulkan rugi-rugi daya yang besarnya berbanding lurus dengan panjang saluran transmisi. Penelitian ini menggunakan metode kuantitatif, dengan cara menghitung besar rugi daya korona dengan membandingkan 4 luas penampang penghantar dan 4 suhu udara yang berbeda. Hasil dari penelitian ini didapatkan bahwa semakin kecil luas penampang kawat maka rugi daya akibat korona semakin kecil, sebaliknya semakin besar luas penampang maka semakin besar rugi daya. Pada luas penampang paling kecil 282,6 $\mathrm{mm}^{2}$ rugi daya yang terjadi sebesar 2,013\% dan pada luas penampang paling besar $378,7 \mathrm{~mm}^{2}$ rugi daya adalah sebesar $5,251 \%$. Sedangkan pengaruh suhu udara, rugi korona terendah terjadi pada suhu $29^{\circ} \mathrm{C}$ yaitu sebesar $1.223,886 \mathrm{~kW}$ dan terbesar terjadi pada suhu $24{ }^{\circ} \mathrm{C}$ yaitu sebesar 1.373,419 $\mathrm{kW}$, sehingga semakin tinggi suhu udara maka semakin kecil rugi korona, sebaliknya semakin rendah suhu udara maka semakin tinggi rugi korona yang terjadi.
\end{abstract}

Kata kunci: Kualitas penyaluran, korona, luas penampang penghantar, pengaruh suhu udara 


\section{PENDAHULUAN}

Saluran transmisi merupakan media yang digunakan untuk mentransmisikan tenaga listrik dari generator station / pembangkit listrik menuju distribution station hingga sampai ke konsumen pengguna listrik. Suatu sistem tenaga listrik terdiri dari tiga bagian utama: pusat-pusat pembangkit listrik, saluran-saluran transmisi, dan sistem-sistem distribusi. Saluran-saluran transmisi juga merupakan rantai penghubung antara pusat-pusat pembangkit listrik dan sistem-sistem distribusi, dan melalui hubungan-hubungan antar sistem dapat pula menuju ke sistem tenaga yang lain. Suatu sistem distribusi menghubungkan semua beban-beban yang terpisah satu dengan yang lain kepada saluransaluran transmisi.

Tegangan pada generator-generator besar biasanya berkisar diantara $13,8 \mathrm{kV}$ dan $24 \mathrm{kV}$. Tetapi generator-generator besar yang modern dibuat dengan tegangan yang bervariasi antara 18 dan $24 \mathrm{kV}$. Tidak ada suatu standar yang umum diterima untuk tegangan-tegangan generator. Tegangan generator dinaikkan ke tingkat-tingkat yang dipakai untuk transmisi yaitu antara $70 \mathrm{kV}, 150 \mathrm{kV}$, dan $275 \mathrm{kV}$. Tegangan-tegangan tinggi-ekstra (extra high voltage - EHV) adalah $500 \mathrm{kV}$. Kini sedang dilakukan penelitian untuk pemakaian tegangan-tegangan tinggi ultra yaitu $1000 \mathrm{kV}$ (ultrahigh voltages $-U H V)$. Keuntungan dari transmisi dengan tegangan yang lebih tinggi adalah mengurangi nilai rugi-rugi daya transmisi.

Kemampuan transmisi dari suatu saluran dengan tegangan tertentu tidak dapat ditetapkan dengan pasti, karena kemampuan ini masih tergantung lagi pada batasan-batasan (limit) thermal dari penghantar, jatuh tegangan (voltage drop) yang diperbolehkan, keterandalan, dan persyaratanpersyaratan kestabilan sistem (system stability), yaitu penjagaan bahwa mesin-mesin pada sistem tersebut tetap berjalan serempak satu terhadap yang lain. Kebanyakan faktor-faktor ini masih tergantung pula pada panjangnya saluran.

Dalam penyaluran daya listrik ke konsumen akan mengalami rugi daya penyaluran yang besarnya sebanding dengan panjang saluran. Menaikkan tegangan adalah alternatif dari masalah ini namun menimbulkan permasalahan baru karena semakin tinggi tegangan dinaikan akan menimbulkan peristiwa korona.

Korona merupakan proses dimana arus, mungkin diteruskan, muncul dari sebuah elektroda berpotensial tinggi di dalam sebuah fluida yang netral, dengan mengionisasi fluida hingga menciptakan plasma di sekitar elektroda. Bila dua kawat sejajar yang penampangnya kecil dibandingkan dengan jarak antar kawat tersebut diberi tegangan, maka akan terjadi korona. Pada tegangan yang cukup rendah tidak terlihat apa-apa, bila tegangan dinaikkan maka akan tejadi korona secara bertahap. Pertama kali, kawat kelihatan bercahaya yang berwarna ungu muda, mengeluarkan suara erdesis (hissing) dan berbau ozon. Jika tegangan dinaikkan terus, maka karakteristik diatas akan terlihat semakin jelas, terutama pada bagian yang kasar, runcing atau kotor serta cahaya bertambah besar dan terang. Bila tegangan masih terus dinaikkan akan terjadi busur api.

Korona bisa bermuatan positif atau negatif. Hal ini ditentukan oleh polaritas tegangan di elektroda yang kelengkungannya tinggi. Jika elektroda bemuatan positif berkenaan dengan elektoda rata terciptalah korona positif, api jika negatif yang tercipta adalah korona negatif.

Inception Voltage korona atau tegangan awal korona didefinisikan sebagai tegangan yang terukur pada saat terjadi lucutan pertama kali saat pengujian dilakukan. Definisi ini sebagai acuan untuk mendapatkan nilai inception voltage secara langsung, dikarenakan pada pengujiannya tidak digunakan oscilloscope untuk mendapatkan sinyal yang menunjukkan awal terjadi korona. Adapun faktor-faktor yang mempengaruhi terjadinya korona adalah:

1. Kondisi Atmosfer.

2. Diameter Konduktor. 
3. Kondisi Permukaan Konduktor.

4. Jarak Konduktor antar fasa.

5. Tegangan.

Lima faktor diatas menjadi penentu perhitungan terhadap gradien tegangan permukaan konduktor. Gradien tegangan permukaan konduktor merupakan faktor yang mempengaruhi besar nilai rugi korona.

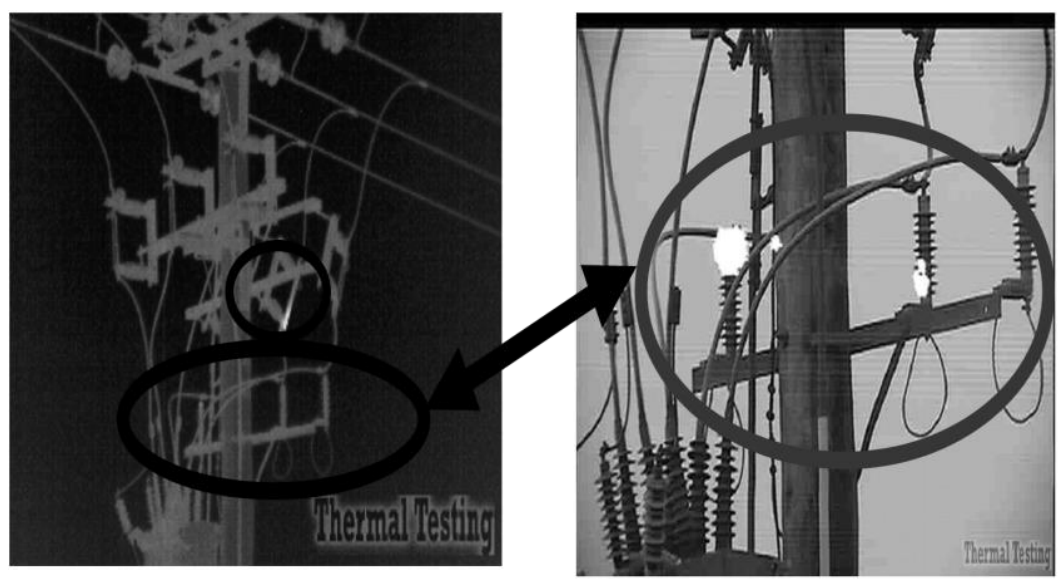

Gambar 1. Peristiwa korona tampak dengan Thermography dan UV Camera

Bila dua kawat sejajar yang penampangnya kecil (dibandingkan dengan jarak dua elektroda tersebut) diberi tegangan bolak-balik maka terjadi fenomena korona. Pada tegangan yang cukup rendah fenomena korona tidak akan terjadi. Bila tegangan dinaikan, maka peristiwa korona akan terjadi secara bertahap. Pertama-tama, pada kawat penghantar kelihatan bercahaya yang berwarna ungu muda, mengeluarkan suara berdesis ( hissing ) dan berbau ozon. Jika tegangan dinaikkan terus, maka karakteristik diatas akan terlihat semakin jelas, terutama pada bagian yang kasar, runcing atau kotor serta cahaya bertambah besar dan terang. Bila tegangan masih terus dinaikkan akan terjadi busur api. Korona akan mengeluarkan panas, hal ini dapat dibuktikan dengan melakukan pengukuran dengan mengguanakan wattmeter.

Dalam keadaan udara lembab, korona menghasilkan asam nitrogen (Nitrous Acid) yang menyebabkan kawat menjadi berkarat bila kehilangan daya yang cukup besar. Apabila tegangan searah yang diberikan, maka pada kawat positif korona menampakkan diri dalam bentuk cahaya yang seragam pada permukaan kawat, sedangkan pada kawat negatifnya hanya pada tempat-tempat tertentu saja.

Korona terjadi karena adanya ionisasi dalam udara, yaitu adanya kehilangan elektron dari molekul udara. Karena terjadinya ionisasi molekul dalam udara, maka molekul netral di udara bebas mendapatkan energi foton yang cukup dan besarnya melebihi energi yang diperlukan untuk membebaskan elektron dari molekul gas atau udara. Kelebihan energi foton dilimpahkan pada elektron yang kemudian di bebaskan dalam bentuk energi kinetik.

Korona pada saluran transmisi dapat menyebabkan beberapa gangguan yaitu rugi-rugi daya, kerusakan bahan isolasi, noise dan interferensi radio. Rugi-rugi korona (corona losses) dipengaruhi oleh pengaruh cuaca, konfigurasi macam kawat, keadaan permukaan konduktor dan luas penampang kawat. Bila dua kawat sejajar yang penampangnya kecil (dibandingkan dengan jarak antara dua kawat tersebut) diberikan tegangan bolak-balik, maka korona dapat terjadi. Bila tegangan dinaikkan 


\section{Energi dan Kelistrikan: Jurnal Ilmiah}

Vol. 11, No. 2, Juli - Desember 2019, P-ISSN 1979-0783, E-ISSN 2655-5042

https://doi.org/10.33322/energi.v11i2.857

lagi maka akan terjadi busur api. Korona mengeluarkan panas hal ini dapat dilakukan pengukuran dengan Watt meter.

Karena selain faktor cuaca pada peristiwa korona, faktor luas penampang pada SUTT $150 \mathrm{kV}$ juga berpengaruh besar terhadap terjadinya peristiwa korona, maka dalam penelitian ini penulis akan melihat seberapa besar pengaruh luas penampang penghantar dan cuaca terhadap rugi-rugi korona dengan memvariasikan luas penampang penghantar pada saluran transmisi tersebut, dengan standar losses yang diberikan oleh PT. PLN sebesar 10\%.

Berdasarkan hal diatas maka pada penelitian ini fokus pada analisa pengaruh luas penampang penghantar dan cuaca terhadap terjadinya rugi daya akibat korona pada SUTT $150 \mathrm{kV}$ dengan studi kasus pada Gardu Induk Bangkalan ke Gardu Induk Sampang.

\section{METODE PENELITIAN}

Penelitian ini menggunakan teknik analisis data statistika. Data-data yang diperoleh dari pengumpulan data diolah dengan menggunakan persamaan-persamaan terentu. Persamaanpersamaan tersebut digunakan untuk membandingkan pengaruh luas penampang kawat dan pengaruh cuaca terhadap rugi-rugi daya akibat korona.

\subsection{Suhu Udara Rata-rata}

Permukaan bumi menerima panas dari penyinaran matahari berupa radiasi gelombang elektromagnetik. Radiasi sinar matahari yang dipancarkan ini tidak seluruhnya sampai ke permukaan bumi. Hal ini dikarenakan pada saat memasuki atmosfer, berkas sinar matahari tersebut mengalami pemantulan (refleksi), pembauran (scattering), dan penyerapan (absorpsi) oleh material-material di atmosfer. Suhu udara rata-rata dalam satu tahun merupakan rata-rata suhu udara yang diamati dalam 24 jam setiap hari dalam satu tahun terus menerus. Suhu udara rata-rata ini dapat dihitung dengan menggunakan persamaan:

Suhu udara rata-rata $=\frac{\text { Jumlah suhu udara setiap bulan dalam setahun }}{12}$

\subsection{Tekanan Udara Pada Ketinggian Tertentu}

Besarnya tekanan udara di suatu tempat sangat bergantung pada jumlah udara diatasnya. Semakin tinggi suatu tempat maka semakin sedikit jumlah udara diatasnya, dan semakin sedikit berat udara yang ditahan wilayah tersebut sehingga tekanannya semakin sedikit. Berbanding terbalik dengan daerah atau dataran rendah, mereka mempunyai tekanan udara yang lebih besar. Jadi tekanan udara di suatu wilayah sangat ditentukan oleh ketinggian tempat atau wilayah tersebut dari permukaan air laut. Untuk menentukan tekanan udara disuatu tempat menggunakan persamaan:

$\mathrm{Ph}=(\mathrm{Pu}-\mathrm{h} / 100) \mathrm{cmhg}$

dimana:

$$
\begin{aligned}
& \mathrm{Ph}=\text { tekanan udara pada ketinggian } \mathrm{h}(\mathrm{cmhg}) \\
& \mathrm{Pu}=\text { tekanan udara pada permukaan laut }(\mathrm{cmhg}) \\
& \mathrm{h} \quad=\text { ketinggian tempat (mdpl) }
\end{aligned}
$$




\subsection{Faktor Kerapatan Udara}

Kerapatan udara akan berkurang bila semakin tinggi, dapat juga disebutkan kerapatan akan lebih rendah karena di bawah kondisi atmosfir standar, udara pada setiap tingkat di atmosfer tidak hanya memiliki kerapatan tertentu, tetapi juga tekanan dan kerapatan mengidentifikasi tingkat yang sama. Kerapatan udara bervariasi secara langsung dengan tekanan, dan berbanding terbalik dengan suhu. Kerapatan udara dipengaruhi oleh perubahan ketinggian, suhu, dan kelembaban. dengan menggunakan persamaan:

$\delta=\frac{0,386 p}{(273+t)}$

dimana:

$$
\begin{aligned}
\delta & =\text { faktor kepadatan udara } \\
P & =\text { tekanan udara }(\mathrm{mmHg}) \\
\dagger & =\text { suhu udara }\left({ }^{\circ} \mathrm{C}\right)
\end{aligned}
$$

\subsection{Tegangan Kritis Disruptif}

Tegangan kritis disruptif merupakan tegangan minimal yang dibutuhkan untuk terjadinya ionisasi pertama kali dipermukaan konduktor. Berdasarkan hasil penelitian yang dilakukan oleh Peek's, kekuatan dielektrik udara maksimum pada kodisi standar dengan tekanan udara $1 \mathrm{~atm}$ (760 $\mathrm{mmHg}$ ), suhu udara $25^{\circ} \mathrm{C}$ adalah $30 \mathrm{kV} / \mathrm{cm}$, dengan menggunakan persamaan:

$\mathrm{V}_{\mathrm{d}}=\mathrm{g}_{\mathrm{m}} \cdot \mathrm{m}_{0} \cdot \delta \cdot r \cdot \ln \frac{D}{r}$

dimana:

$$
\begin{aligned}
\mathrm{V}_{d} & =\text { tegangan kritis disruptif fasa ke netral }(\mathrm{kVrms}) \\
g_{m} & =\text { gradien tegangan permukaan maksimum }(\mathrm{kVrms} / \mathrm{cm}) \\
& =\text { keadaan kering mempunyai nilai } 21,1 \mathrm{kVrms} / \mathrm{cm} \\
& =\text { keadaan basah mempunyai nilai } 16,9 \mathrm{kVrms} / \mathrm{cm} \\
r & =\text { jari-jari konduktor } \\
D & =\text { jarak antar fasa } \\
m_{0} & =\text { faktor keseragaman konduktor } \\
& =1 \text { untuk konduktor silinder solid dengan permukaan mulus } \\
& =0.92<m_{0}<0.94 \text { untuk permukaan konduktor kasar } \\
& =0.82 \text { konduktor pilin (stranded) } \\
\delta & =\text { Faktor kepadatan udara }
\end{aligned}
$$

\subsection{Rugi-rugi Korona}

Faktor yang mempengaruhi terjadinya korona antara lain cuaca, luas penampang kawat, bentuk permukaan kawat, dan jarak antar penghantar kawat. Dari terjadinya korona tersebut, maka akan timbul rugi-rugi daya akibat korona. Untuk menghitung rugi-rugi daya tersebut menggunakan persamaan: 
$\mathrm{P}_{\mathrm{k}}=\frac{241}{\delta}(f+25) \sqrt{\frac{r}{D}}(V-V d)^{2} \times 10^{-5}$

dimana:

$$
\begin{array}{ll}
\mathrm{P}_{\mathrm{k}} & =\text { rugi-rugi korona } \\
\delta & =\text { faktor kepadatan udara } \\
f & =\text { frekuensi }(\mathrm{Hz}) \\
r & =\text { jari-jari kawat }(\mathrm{cm}) \\
\mathrm{D} & =\text { jarak antar kawat }(\mathrm{cm}) \\
V & =\text { tegangan kawat ke netral, } \mathrm{kV} \text { rms } \\
V d & =\text { tegangan distruktif kritis, } \mathrm{kV} \mathrm{rms}
\end{array}
$$

\subsection{Data Teknis Penghantar dan Suhu}

Penelitian ini data teknis diperoleh dari PT. PLN (Persero) TJBTB Area Pelaksana Pemeliharaan Surabaya dan juga data klimatologi dari BMKG. Perhitungan rugi-rugi daya akibat korona dilakukan pada penampang kawat yang digunakan pada saluran transmisi di wilayah Madura, Surabaya dan Gresik yaitu : 282,6 $\mathrm{mm}^{2} ; 328,5 \mathrm{~mm}^{2} ; 369,1 \mathrm{~mm}^{2}$; dan $378,7 \mathrm{~mm}^{2}$ serta cuaca pada tahun 2017 (Bangkalan-Sampang) dan cuaca pada tanggal 16 Juli 2018 setiap pukul 00:00, 06:00, 12:00, dan 18:00 (Bangkalan-Sampang).

Data-data teknis yang digunakan pada penelitian ini adalah data berdasarkan aplikasi penelitian yaitu dari GI Bangkalan ke GI Sampang yang di tunjukan pada tabel 1 berikut.

Tabel 1. Data teknis saluran transmisi 150 kV GI Bangkalan ke GI Sampang

\begin{tabular}{|c|l|l|}
\hline No & \multicolumn{1}{|c|}{ Jenis Data } & \multicolumn{1}{c|}{ Keterangan } \\
\hline 1 & Tegangan Operasi & $150 \mathrm{kV}$ \\
\hline 2 & Transmisi & GI Bangkalan ke GI Sampang \\
\hline 3 & Panjang Saluran & $55,369 \mathrm{~km}$ \\
\hline 4 & Jenis Kawat Penghantar & ACSR Hawk $/ 240 / 40 \mathrm{~mm}^{2}$ \\
\hline 5 & Luas Penampang Luar & $282,6 \mathrm{~mm}^{2}$ \\
\hline 6 & Diameter Luar & $21,84 \mathrm{~mm}$ \\
\hline 7 & Jarak Antar Fasa & $4,3 \mathrm{~m}=430 \mathrm{~cm}$ \\
\hline 8 & Jumlah Kawat Fasa & $3 \mathrm{Buah}$ \\
\hline 9 & Banyak Urat Alluminium & $26 \mathrm{Buah}$ \\
\hline 10 & Banyak Urat Untuk steel & 7 Buah \\
\hline
\end{tabular}

Data yang digunakan untuk memvariasikan luas penampang kawat $\left(240 \mathrm{~mm}^{2}\right)$ diambil berdasarkan data saluran transmisi di wilayah Madura, Gresik, dan Surabaya seperti pada tabel 2 berikut:

Tabel 2. Data luas penampang kawat yang digunakan dalam perhitungan

\begin{tabular}{|c|c|c|c|}
\hline No & $\begin{array}{c}\text { Luas penampang } \\
\left(\mathbf{m m}^{\mathbf{2}}\right)\end{array}$ & $\begin{array}{c}\text { Diameter kawat } \\
(\mathbf{c m})\end{array}$ & $\begin{array}{c}\text { Jari-jari kawat } \\
(\mathbf{c m})\end{array}$ \\
\hline 1 & 282,6 & 2,184 & 1,092 \\
\hline 2 & 328,5 & 2,360 & 1,180 \\
\hline 3 & 369,1 & 2.499 & 1.2495 \\
\hline 4 & 378,7 & 2.53 & 1.265 \\
\hline
\end{tabular}


Data klimatologi untuk daerah Bangkalan sampai ke daerah Sampang diperoleh dari Badan Meteorologi dan Geofisika (BMKG) seperti yang ditunjukan pada tabel 3. Data klimatologi ini adalah data untuk periode tahun 2017 (Januari - Desember) dan yang diambil pada tanggal 16 Juli 2018.

Table 3. Data klimatologi BMKG

\begin{tabular}{|c|l|l|}
\hline No & \multicolumn{1}{|c|}{ Jenis Data } & \multicolumn{1}{|c|}{ Keterangan } \\
\hline 1 & Ketinggian Diatas Permukaan Laut & $47 \mathrm{~m}(154,199 \mathrm{ft})$ \\
\hline 2 & Suhu udara rata-rata tahun 2017 & $27,508{ }^{\circ} \mathrm{C}$ \\
\hline 3 & Suhu udara (pukul 00.00) & $24{ }^{\circ} \mathrm{C}$ \\
\hline 4 & Suhu udara (pukul 06.00) & $25^{\circ} \mathrm{C}$ \\
\hline 5 & Suhu udara (pukul 12.00) & $29{ }^{\circ} \mathrm{C}$ \\
\hline 6 & Suhu udara (pukul 18.00) & $27{ }^{\circ} \mathrm{C}$ \\
\hline
\end{tabular}

\section{HASIL DAN PEMBAHASAN}

\subsection{Rugi-rugi Korona Dengan Luas Penampang Berbeda}

\subsubsection{Kondisi Cuaca Cerah}

Hasil perhitungan rugi korona pada SUTT $150 \mathrm{kV}$ dari GI Bangkalan ke GI Sampang, panjang saluran 55,369 $\mathrm{km}$ pada kondisi cuaca cerah dengan 4 luas penampang berbeda berdasarkan persamaan-persamaan di atas ditunjukkan pada Tabel 4 berikut:

Tabel 4. Hasil perhitungan rugi korona SUTT $150 \mathrm{kV}$ pada cuaca cerah

\begin{tabular}{|c|c|c|c|c|c|}
\hline No & $\begin{array}{c}\text { Luas } \\
\text { penampang } \\
\left(\mathbf{m m}^{\mathbf{2}}\right)\end{array}$ & $\begin{array}{c}\text { Jari-jari } \\
\text { kawat } \\
(\mathbf{c m})\end{array}$ & $\begin{array}{c}\text { Tegangan } \\
\mathbf{k r i t i s}(\mathbf{k V})\end{array}$ & $\begin{array}{c}\text { Rugi-rugi } \\
\text { korona } \mathbf{P}_{\mathbf{k}} \\
\mathbf{( k W / f a s a} / \mathbf{k m})\end{array}$ & $\begin{array}{c}\text { Rugi-rugi } \\
\mathbf{k o r o n a} \\
\mathbf{P}_{\mathbf{k 3 f a s a}}(\mathbf{k W})\end{array}$ \\
\hline 1 & 282,6 & 1,092 & 115,265 & 7,59783 & $1.262,0527$ \\
\hline 2 & 328,5 & 1,180 & 122,95447 & 12,70349 & $2.110,13861$ \\
\hline 3 & 369,1 & 1,2495 & 128,93302 & 16,57282 & $2.752,8441$ \\
\hline 4 & 378,7 & 1,265 & 130,96654 & 18,96652 & $3.150,37173$ \\
\hline
\end{tabular}

Pada Tabel 4 dapat dilihat bahwa pada cuaca cerah semakin besar luas penampang kawat maka tegangan kritis dan rugi-rugi daya yang di akibatkan korona pada saluran transmisi semakin tinggi. Hal ini bisa juga dilihat pada Gambar 2 yaitu karakteristik pengaruh luas penampang terhadap rugi korona berikut, 


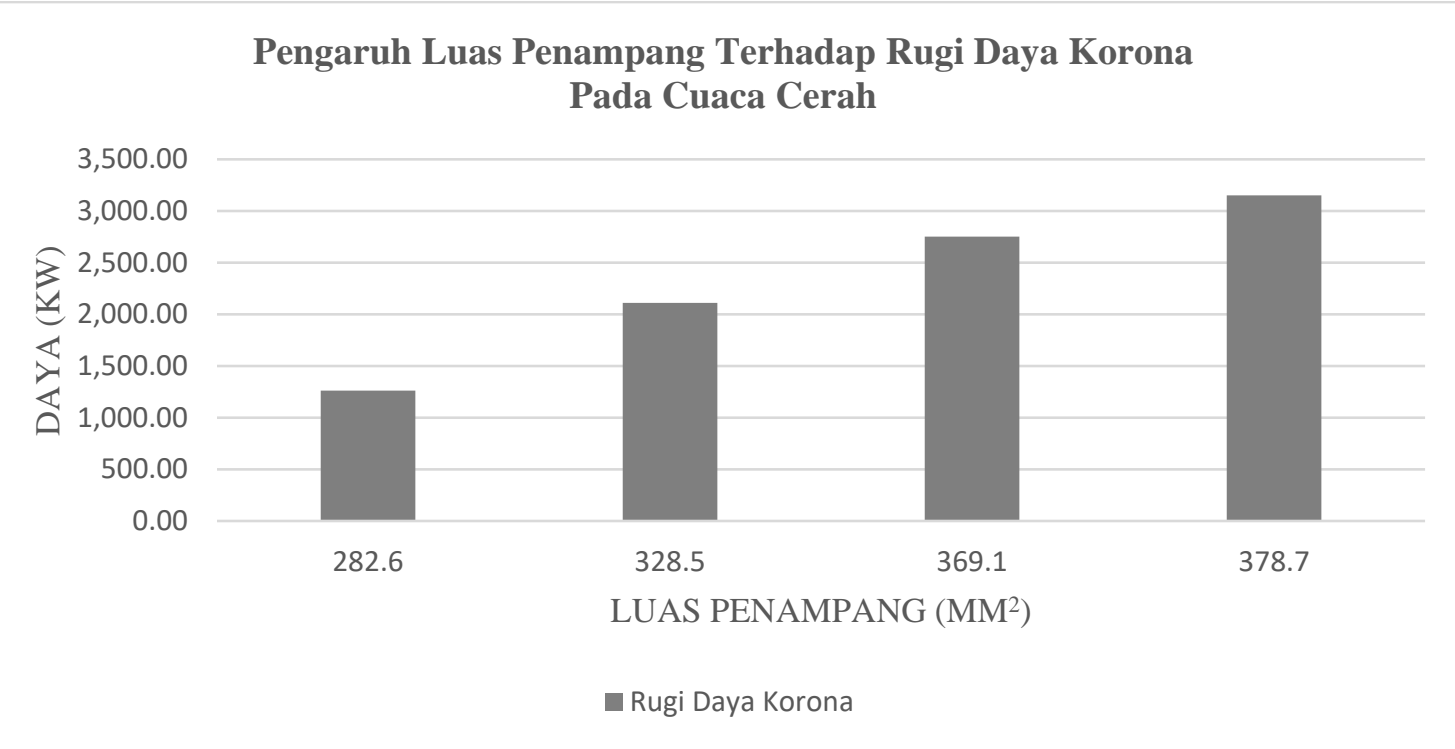

Gambar 2. Karakteristik luas penampang terhadap rugi rugi korona pada kondisi cuaca cerah

Dari gambar 2 terlihat bahwa antara luas penampang dengan rugi-rugi korona berbanding lurus, semakin besar luas penampang maka rugi-rugi korona semakin tinggi, dan sebaliknya semakin kecil luas penampang maka rugi-rugi korona semakin semakin kecil.

\subsubsection{Kondisi Cuaca Hujan}

Hasil perhitungan rugi korona yang terjadi pada SUTT $150 \mathrm{kV}$ antara GI Bangkalan ke GI Sampang dengan panjang saluan 55,369 km pada saat cuaca hujan di tunjukan pada Tabel 5 berikut:

Table 5. Hasil perhitungan Rugi korona pada SUTT $150 \mathrm{kV}$ pada cuaca hujan.

\begin{tabular}{|c|c|c|c|c|c|}
\hline No & $\begin{array}{c}\text { Luas penampang } \\
\text { kawat aluminium } \\
\left(\mathbf{m m}^{2}\right)\end{array}$ & $\begin{array}{c}\text { Jari-jari } \\
\text { kawat } \\
(\mathbf{c m})\end{array}$ & $\begin{array}{c}\text { Tegangan } \\
\mathbf{k r i t i s}(\mathbf{k V})\end{array}$ & $\begin{array}{c}\text { Rugi-rugi } \\
\mathbf{k o r o n a} \mathbf{P}_{\mathbf{k}} \\
(\mathbf{k W / f a s a / k m )}\end{array}$ & $\begin{array}{c}\text { Rugi-rugi } \\
\text { korona } \mathbf{P}_{\mathbf{k 3} \text { 3asa }} \\
(\mathbf{k W})\end{array}$ \\
\hline 1 & 282,6 & 1,092 & 92,32125 & 0,30266 & 50,27546 \\
\hline 2 & 328,5 & 1,180 & 98,48012 & 1,35659 & 225,33936 \\
\hline 3 & 369,1 & 1,2495 & 103,26862 & 2,56943 & 426,80085 \\
\hline 4 & 378,7 & 1,265 & 104,32900 & 3,12788 & 519,56287 \\
\hline
\end{tabular}

Karakteristik penampang kawat terhadap rugi-rugi korona dapat dilihat pada gambar 3 berikut: 


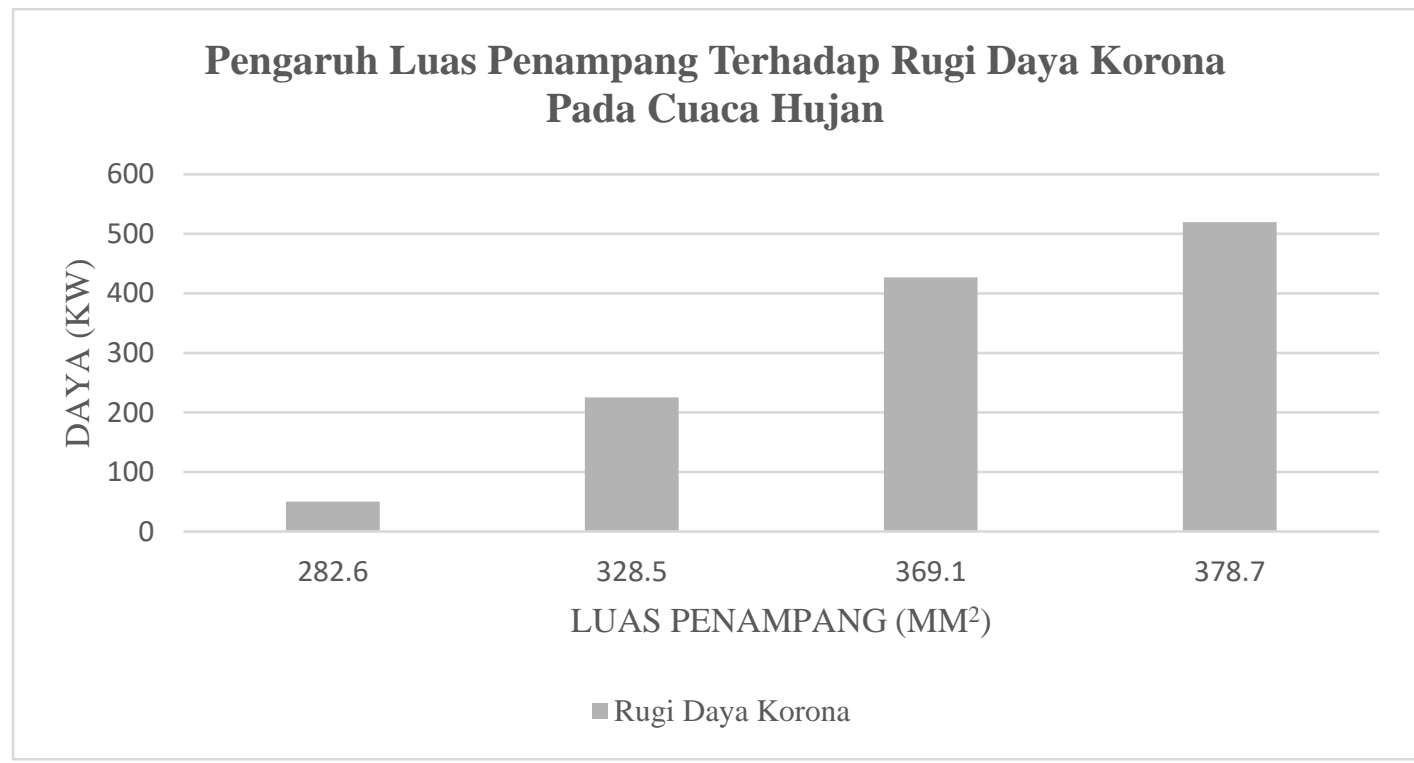

Gambar 3. Karakteristik luas penampang terhadap rugi korona pada kondisi cuaca hujan

Sama halnya dengan cuaca cerah, pada keadaan cuaca hujan pun semakin besar luas penampang maka rugi-rugi korona yang terjadi pada saluran transmisi semakin tinggi, dan sebaliknya semakin kecil luas penampang pada saluran transmisi maka rugi-rugi korona juga semakin kecil. Pada luas penampang terkecil $282,6 \mathrm{~mm}^{2}$ rugi-rugi koronanya adalah $50,27546 \mathrm{~kW}$ dan pada luas penampang terbesar yakni $378,7 \mathrm{~mm}^{2}$, rugi rugi korona yang terjadi adalah $519,56287 \mathrm{~kW}$.

Jika dibandingkan dari kedua keadaan cuaca tersebut cuaca cerah dengan cuaca hujan, maka rugi-rugi korona pada cuaca hujan lebih kecil dari cuaca cerah, hal ini dikarenakan hujan dapat meningkatkan faktor hilang korona (memperkecil korona), terlihat pada Gambar 4 berikut:

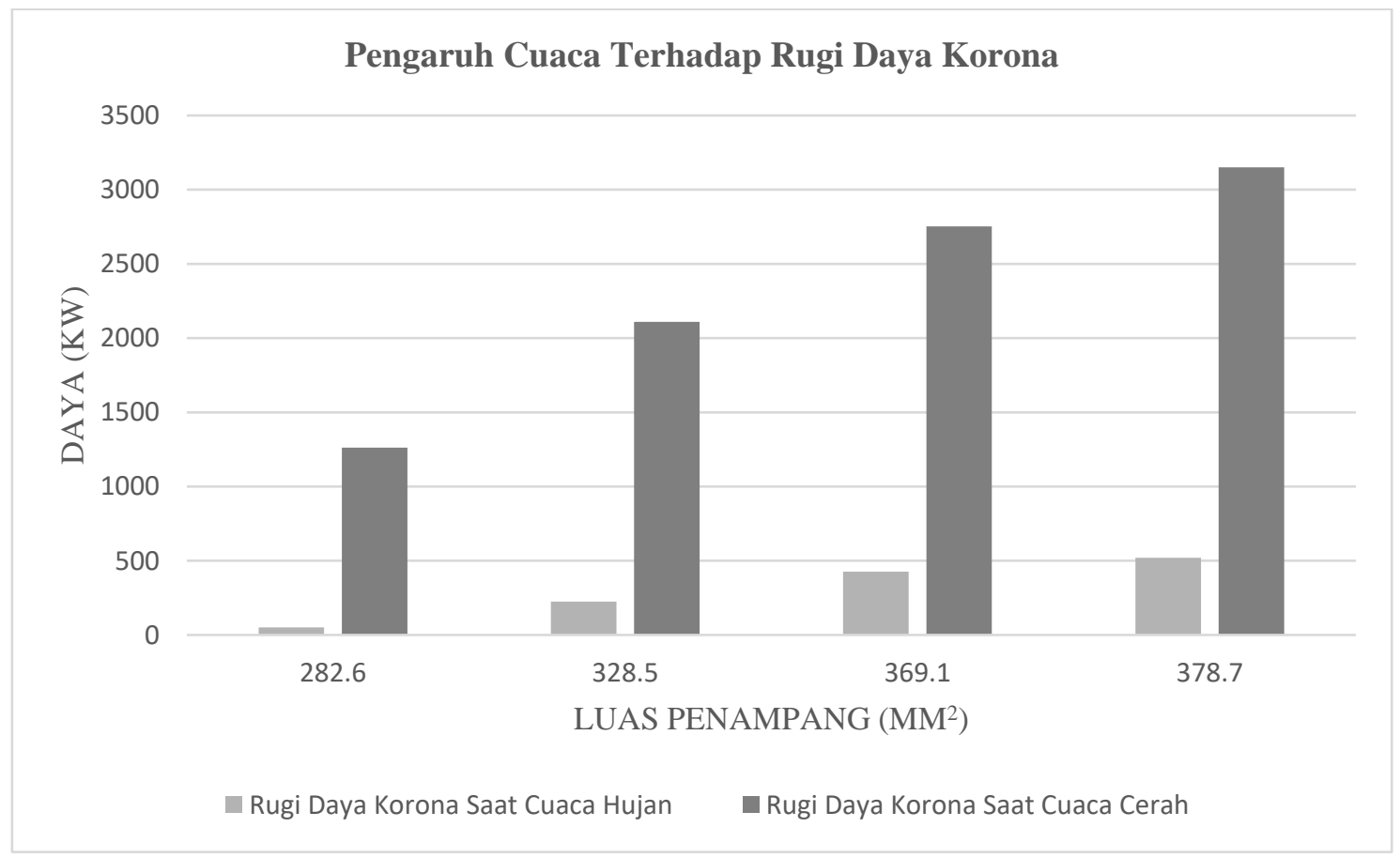

Gambar 4. Karakteristik luas penampang terhadap rugi korona pada kondisi cuaca hujan dan cerah 


\subsection{Rugi-rugi Korona Dengan Cuaca Berbeda}

Hasil perhitungan rugi korona pada 4 kondisi suhu berbeda yaitu $24{ }^{0} \mathrm{C}, 25{ }^{0} \mathrm{C}, 27{ }^{0} \mathrm{C}$, dan 29 ${ }^{0} \mathrm{C}$ pada SUTT $150 \mathrm{kV}$ antara GI Bangkalan ke GI Sampang dengan panjang saluran 55,369 km dengan menggunakan persamaan-persamaan di atas diperoleh seperti pada Tabel 6 berikut:

Tabel 6. Hasil perhitungan Rugi korona SUTT 150 kV GI Bangkalan ke GI Sampang pada suhu berbeda

\begin{tabular}{|c|c|c|c|c|c|c|}
\hline No & $\begin{array}{c}\text { Luas } \\
\text { penampan } \\
\mathbf{g}\left(\mathbf{m m}^{2}\right)\end{array}$ & $\begin{array}{c}\text { Jari-jari } \\
\text { kawat } \\
\text { (cm) }\end{array}$ & $\begin{array}{c}\text { Suhu } \\
\left({ }^{0} \mathrm{C}\right)\end{array}$ & $\begin{array}{c}\text { Tegangan } \\
\text { kritis }(k V)\end{array}$ & $\begin{array}{c}\text { Rugi-rugi } \\
\text { korona } P_{k} \\
(\mathbf{k W} / \text { fasa/km) }\end{array}$ & $\begin{array}{c}\text { Rugi-rugi } \\
\text { korona } \\
\text { P }_{\text {k3fasa }}(\mathbf{k W})\end{array}$ \\
\hline 1 & \multirow{4}{*}{282,6} & \multirow{4}{*}{1,092} & 24 & 116,68455 & 8,26827 & 1373,41913 \\
\hline 2 & & & 25 & 116,21632 & 8,04517 & 1336,36020 \\
\hline 3 & & & 27 & 115,53751 & 7,72571 & 1283,29451 \\
\hline 4 & & & 29 & 114,76508 & 7,36805 & 1223,88559 \\
\hline
\end{tabular}

Hasil perhitungan pada Tabel 6 di atas dapat dilihat bahwa semakin besar suhu udara maka tegangan kritis dan rugi-rugi daya yang di akibatkan korona pada saluran transmisi semakin rendah. Secara grafik dapat dilihat pada Gambar 5 berikut:

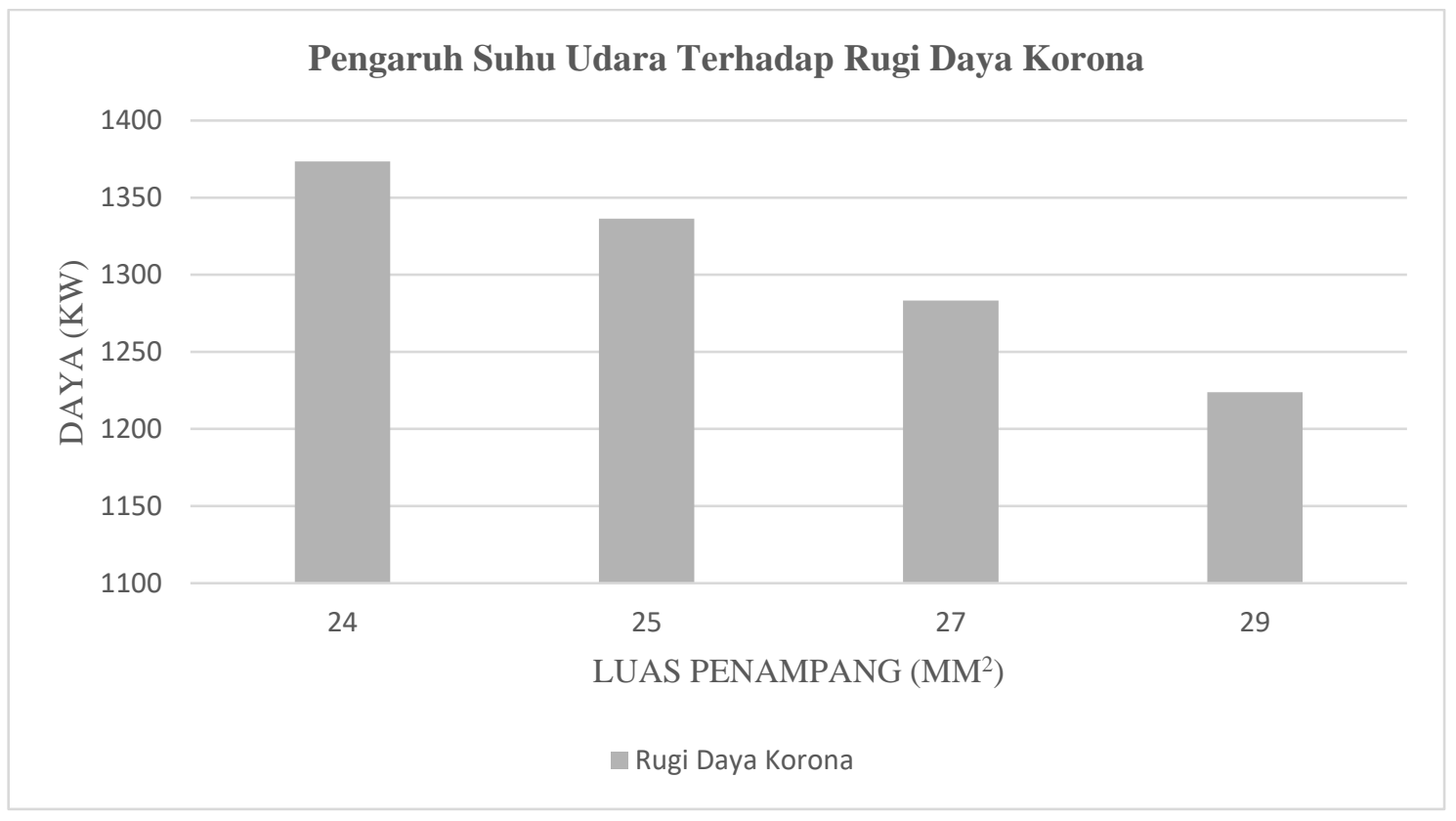

Gambar 5. Karakteristik suhu udara terhadap rugi rugi korona

\section{KESIMPULAN DAN SARAN}

Hasil perhitungan dan analisa data rugi-rugi daya akibat korona yang terjadi pada SUTT 150 $\mathrm{kV}$ antara GI Bangkalan ke GI Sampang dengan panjang saluran 55,369 km, dengan memvariasikan 4 luas penampang kawat yang berbeda serta 4 kondisi suhu udara yang juga berbeda diperoleh bahwa semakin kecil luas penampang kawat maka rugi-rugi daya akibat korona semakin kecil, sebaliknya semakin besar luas penampang maka semakin besar rugi-rugi daya akibat korona. Pada luas penampang paling kecil $282,6 \mathrm{~mm}^{2}$ rugi-rugi daya akibat korona terjadi sebesar 2,0134\% dan pada luas penampang paling besar yaitu $378,7 \mathrm{~mm}^{2}$ rugi-rugi daya akibat korona terjadi sebesar 5,25078 $\%$. Hal ini juga berlaku pada kondisi cuaca hujan. 
Sementara hasil yang diperoleh dengan 4 kondisi suhu berbeda pada penampang kawat 282,6 $\mathrm{mm}^{2}$, rugi-rugi korona terendah terjadi pada suhu $29{ }^{\circ} \mathrm{C}$ yaitu sebesar $1.223,88559 \mathrm{~kW}$ dan rugi-rugi korona terbesar terjadi pada suhu $24{ }^{\circ} \mathrm{C}$ yaitu sebesar $1373,41913 \mathrm{~kW}$. Semakin tinggi suhu udara maka semakin kecil rugi-rugi korona dan semakin rendah suhu udara maka semakin tinggi rugi-rugi korona. Jadi suhu udara dengan rugi-rugi korona berbading terbalik.

\section{UCAPAN TERIMAKASIH}

Penulis mengucapkan terima kasih kepada PT. PLN (Persero) TJBTB Area Pelaksana Pemeliharaan Surabaya yang telah memberi dukungan dan membantu pelaksanaan penelitian ini dengan memberikan izin untuk pengamatan dan pengambilan data untuk penulisan artikel ini dan juga tak lupa mengucapkan terima kasih kepada Badan Meteorolgi, Klimatologi dan Geofisika (BMKG) atas data suhu udara yang diperoleh untuk daerah Bangkalan sampai ke daerah Sampang.

\section{DAFTAR PUSTAKA}

[1] Hutauruk, TS. (1985). Transmisi Daya Listrik. Erlanga. Jakarta

[2] Kurniasih, N., \& Dewi, P. (2014). Analisis Pengaruh Akibat Korona Terhadap Rugi-rugi Daya Saluran Udara Tegangan Tinggi $150 \mathrm{kV}$.

[3] Suastra, M. (2008). Pengaruh Penampang Kawat Terhadap Rugi-Rugi Korona Pada SUTT $150 \mathrm{kV}$.

[4] Peek, F.W. (1915). Dielectric Phenomena.McGraw Hill Book Company, Inc. New York.

[5] Stevenson Jr, William. (1984). Analisis Sistem Tenaga Listrik. Erlangga.

[6] Fanberly, T. (2014). Pengaruh Luas Penampang dan Tegangan Sistem Terhadap Rugi-Rugi Daya Akibat Korona ada Saluran Udara Tegangan Tinggi 150 kV. 